\title{
Discourse Markers Used by Students in Nonformal Education
}

\author{
Atikah Nurul ${ }^{1, *}$ Saragih Amrin ${ }^{2}$ Zainuddin $^{3}$ \\ ${ }^{1}$ English Applied Linguistic Study Program, Post-Graduate, State University of Medan \\ ${ }^{2}$ State University of Medan \\ ${ }^{3}$ State University of Medan \\ *Corresponding author. Email: nurulatikah369@gmail.com
}

\begin{abstract}
In order to achieve a good communication, discourse markers are essentially needed as a tool to perform in connecting or linking the ideas to ideas, especially in spoken language, it helps the speakers and the listener to comprehend what the speaker intended to say. In addition, it makes the conversation feels smooth and organized. In line with that, the objective of this study is to investigate the types of discourse markers applied in students of nonformal education. The source of the data was students' interaction in nonformal education and the data were the words from their utterances contained of types of discourse markers. The research was done by applying descriptive qualitative method. The result revealed that the most dominant types of discourse markers applied by students in their interactions are Response Forms $(28,27 \%)$, and followed by hesitator marker $(21,91 \%)$, it is also found that ' $\mathrm{hmm}$ ' is applied by students as a response forms marker instead of hesitator marker.
\end{abstract}

Keywords: discourse markers, students interactions, nonformal education.

\section{INTRODUCTION}

With no doubt, in delivering the ideas, certain messages or even the purpose of the communication, the expression is needed to be understood based on the meaning of the message is about. And it can be found generally in our language used and communication. Well in order to achieve a good communication, it is needed the tools of language which discourse markers (DMs) are some of them. There are a lot of definitions describes what DMs is, it refers to pieces of language that is larger than a sentence which has function together in delivering idea or information, it is a linguistic device which are applied to hang the pieces of language expression together [10]. It's supported that DMs are words and expressions which were used in order to portray our discourse structurally; they are functioned to serve the purpose of connecting or linking what we are saying, what we have said, and what will be said [11]. Discourse markers (DMs) are the important elements of language in conversation, or in any kind of interactive face-to-face or non-face-to-face spoken exchange. And it is occurring conversation naturally, including classroom talk and phone conversation, they are characterized by discourse markers not only to provide coherence, but also to serve other essential functions such as regulating turns and signalling utterances with actions relevant to those in prior units. In short, DMs refers to words or phrases in order to help readers or even listeners in comprehending a text of the speaker or writer [1]. In conclusion, they play a significant role in achieving the good communication.

There are numerous studies conducted related to discourse markers, one of them discovered that "hmm" found as filler mostly used by students in spontaneous and nonspontaneous utterances [12]. And 19 types of Dms used by teachers in the classroom interaction [4]

The researcher found another phenomenon through this preliminary data which were taken in nonformal education called Harford Institute during the pre-lesson in the class

$T \quad$ :okay, straight up to the questions please

$S(N T H)$ : Miss do you know Jessica Iscandar? Euh the artist?

$T \quad$ : the kid is bule? (foreigner)

$S(N T H)$ : hmm, handsome right miss?

$T \quad$ : ha what about it? 
In the preliminary data above displayed there are two discourse markers used, 'euh' and 'hmm', 'euh' belongs to hesitator discourse markers, while ' $\mathrm{hmm}$ ' there is commonly used as a part of hesitator marker, which is in line with the findings found in the previous research [12], which claimed that "hmm" mostly used as part of hesitator, but in the preliminary data it's found as a response form as a yes.

Based on the phenomenon above, it has been found that this study discussed about the discourse markers used by students in nonformal education called Harford Intitute, this place is an institution that focus on teaching English as a foreign language, in order to prove whether the result would be different or similar with the previous study if it was analysed in students of nonformal education. It has been known that in Indonesia, English is taught as a foreign language (EFL). In EFL atmosphere, people learn English in order to be able to make use of it in communicating with other English speakers around the world [3]. Thus, the types of discourse markers analysis would be the main focus where the students in nonformal education are the source of the data. The classification of discourse markers was conducted in analyzing the types of discourse markers [2]

\section{REVIEW OF LITERATURE}

Discourse markers (DMs) are linguistic components that file various relations and soundness between units of talk [6]. There are developing quantities of studies and research interest on lingusitic things like you know, OK and well that individuals use in composed and spoken setting and featured their importance [6]. Discourse markers are words and expressions that assist you with interfacing your thoughts. Utilizing discourse markers makes your talking more familiar and natural and it might help fill in a portion of the "stops" in your talking. Discourse Markers are grammatical/functioning words. In contrast to content words, they don't pass on significance all alone nor change the importance of a sentence. They just perform grammatical functions by connecting thoughts in a piece of composing. Most discourse markers signal the audience/reader of coherence in text or the connection between the first and following content. Without adequate discourse markers in a piece of composing, a book would not appear to be coherently built and the associations between the various sentences and passages would not be self-evident. Discourse markers are the fourth and last kind of pragmatic markers. Rather than the other pragmatic markers, DMs don't add to the agent sentence meaning, however just to the procedural importance: they give guidance to the on how the expression to which the DMs is appended to be deciphered.
Different Ideas have been made for grouping discourse markers. Be that as it may, various characterizations are conceivable in light of the fact that each investigation centers on specific parts of these markers. The classification is adopted as it proves to be typical and comprehensive [2].

\section{RESEARCH METHOD}

This study is conducted by using descriptive qualitative research design. This research is intended to investigate the types of disocurse markers used by students in nonformal education called Harford Institute. The data of this study were the words of the students uttered in their utterances. There are 16 students with different levels taken as the source of data. Thus, in achieving the types of discourse marker used by students in nonformal education, the researcher chose audio recording to record the utterances uttered by students during the conversation.

\section{RESULTS}

In analyzing the data, the researcher followed three steps of data analysis [5], namely data condensation which is focused on the process of selecting, focusing, abstracting, simplifying and transforming data, data display which is referred to the ways to recognize the information that permits conclusion drawing, and drawing conclusion which is the analysis should be allowed to begin to develop conclusions regarding the study.

There are 10 types of discourse markers has proposed [2]. They consist of Interjection, Greetings \& Farewell Expressions, Linking Adverbials, Stance Adverbials, Vocatives, Response Elicitors, Response Forms, Hesitator, Various Polite Speech-Act Formulate, Expletives. In this research from 10 transcriptions of student's interaction, there were 283 discourse markers applied by the students, as it displayed in the table below,

Table 4.1 Percentage of Discourse Markers Used in Nonformal Education

\begin{tabular}{llll}
\hline No & \multicolumn{1}{c}{ Types of DMs } & $\begin{array}{c}\text { Frequen } \\
\text { cies }\end{array}$ & $\begin{array}{c}\text { Percentages } \\
(\mathbf{\%})\end{array}$ \\
\hline $\mathbf{1}$ & Response Forms & 80 & 28.27 \\
$\mathbf{2}$ & Hesitator & 62 & 21.91 \\
\hline $\mathbf{3}$ & Linking Adverbials & 48 & 16.96 \\
\hline $\mathbf{4}$ & Interjection & 25 & 8,83 \\
\hline $\mathbf{5}$ & Vocatives & 19 & 6.71 \\
\hline $\mathbf{6}$ & Stance Adverbials & 16 & 5.65 \\
\hline $\mathbf{7}$ & Response Elicitors & 14 & 4.95 \\
\hline $\mathbf{8}$ & Various Polite & 9 & 3.18 \\
& $\begin{array}{l}\text { Speech-Act } \\
\text { Formulate }\end{array}$ & & \\
\hline $\mathbf{9}$ & Greetings \& & 5 & 1.77 \\
& Farewell & & \\
\hline & & & \\
\hline
\end{tabular}




\begin{tabular}{llll}
\hline \multicolumn{3}{c}{ Expressions } & \\
\hline $\mathbf{1 0}$ & Expletives & 5 & 1.77 \\
\hline & TOTAL & $\mathbf{2 8 3}$ & $\mathbf{1 0 0 \%}$ \\
\hline
\end{tabular}

It can be concluded that the most dominant type of discourse markers used is Response Forms and otherwise the smallest usage of type of discourse markers are Greetings and Expletives which both amount the same $5(1.77 \%)$. In this research, the researcher found there were some discourse markers applied by the students which is not categorized or described in the theory [2], those are "lah" and which found in the utterances uttered by students "ya loh", "no lah", "Laah!", "of course lah". This caused because those words categorized typically Indonesian. The reason also derived those students often used that as part of their habits. And in this research also found that there was incompatibility with the example of the type proposed [2], which students uttered "hmmm" as a response form of agreement instead of hesitators, "duuh" was found in students' speech as a hesitator marker instead of interjections, and also "aaah" and "aaa" was used as a hesitator marker, and "eh" is appeared as an interjection marker.

\section{DISCUSSION}

There are numerous studies related to Discourse Markers along with the types, functions, and locations. The first research question of this study dealt with the types of discourse markers utilized by students in nonformal education, as it's classified, there were 10 types of discourse markers, they are Interjection, Greetings \& Farewell Expressions, Linking Adverbials, Stance Adverbials, Vocatives, Response Elicitors, Response Forms, Hesitator, Various Polite Speech-Act Formulate, Expletives [2]. And those types mentioned were conducted in analyzing the data in this reseacrh; it has been revealed there are 283 discourse markers found in the student utterances which have been classified into the types.

And the outcome showed that the most occurences of kinds of discourse markers in this research is Response Markers which divided into three classifications, they are response to questions such as yes, no, yeah; response to directives such as ok, okay and response to assestions or as an uptakers such as yes, yah, i see, yaps, and this research found hmm as a response to agreement, followed by Hesitator Markers eumm, uh, aaah, duuh. It is contradictory with the other research done revealed $\mathrm{hmm}$ which function as a pause filler is mostly found in the Spontaneous and Nonspontaneous utterances uttered by the first year students of English Department while yes, oh, well, I see are the other markers which frequently used after hmm [12]. In addition, two Indonesian allomorphs ya and iya that are equal in meaning to English words yes or yeah. Both are considered discourse markers which can be used to show agreement [13]. Otherwise in this study it has been found that hmm also applied as an agreement of a response form and it's occurred in the initial position, also argues that Indonesian discourse marker ya has a similar function as a question tag in English [13], it is in line with the findings in this research that ya was also discovered as a question tag but followed by kan at the end, so it's "ya kan" and "no kan" which referred to negative connotation.

\section{AUTHORS' CONTRIBUTIONS}

The findings of the research are expected to add up new horizons in pragmatic study. In addition, hopefully, the findings will explore the new ideas for other researchers in investigating the language used in social context along with its functions in society itself, and also be able to give much contributions and insights to apply linguistics particularly in English which can be used as a reference for the similar study with different focus or object in the future. Briefly, the findings can add up more horizons to linguistics and also as a guide line for other researchers to conduct the further research related to pragmatic study

\section{ACKNOWLEDGMENTS}

Researchers would like to express deep gratitude to anyone involved in helping in the form of support and guidance related to the completion of this research, especially to Prof, Dr, Amrin Saragih, MA., Ph.D and also Prof, Zainuddin, M.Pd who have helped the author finishing this research, and thanks to Annual International Seminar on Transformative Education and Educational Leadershi (AISTEEL) 2020, and the reviewers who have provided the opportunity for the author to share this research in terms of helping author, so that this research can be completed properly.

\section{REFERENCES}

[1] Bantawig, B, R. The Role of Discourse Markers in the Speeches of Selected Asian Presidents. Elsevier. 2017

[2] Biber, D., S, Johnason, G, Leech., S, Gonard., and E, fngegan. The Longman Grammar of spoken and written English. London: Longman. 1999.

[3] Harmer, Jeremy. The Practice of English Language Teaching, Fourth. Edition. Pearson Longman: Harlow. 2007.

[4] Karlina, Y., Suparno, S., \& Setyaningsih, E. The Little Words That Matter: Discourse Markers in Teacher Talk. 2015.

[5] Miles, M B., A, M Huberman and J, Saldana. Qualitative Data Analysis: A Methods Sourcebook 3rd Edition. Los Angeles: Sage Publications. 2014. 
[6] Schriffin, D. Discourse Markers. New York: Cambridge University Press. 1987

[7] Schriffin, D. Discourse Markers Types. Cambridge: Cambridge University Press. 1987

[8] Schriffin, D. Discourse Analysis. Cambridge: Cambridge University Press. 1994

[9] Schriffin, D. Discourse Markers: The Role of Intonation In Discourse Markers. 1987

[10] Sharndama. E. C and S. Yakubu. An Analysis Of Discourse Markers In Academic Report Writing: Pedagogical Implications. International Journal of Academic Research and Reflection Vol. 1 No. 3. 2013.

[11] Swan, M. Practical English Usage. OXFORD. 2005.

[12] Trihartanti, P. R. An Analysis on the Different Use of Discourse Markers in Spontaneous and Nonspontaneous Utterances. Advances in Social Science, Education and Humanities Research (ASSEHR), Vol 82. 2017.

[13] Wouk, F. Solidarity in Indonesian conversation: The discourse marker ya. Journal of Pragmatics, 33(2), $171-191$ 2001. https://doi.org/10.1016/S0378-2166(99)00139-3. 